O. DARIUSZ BOREK O.Carm.

Wydział Prawa Kanonicznego

Uniwersytetu Kardynała Stefana Wyszyńskiego w Warszawie

\title{
DELICTA GRAVIORA CONTRA MORES W NORMACH DE DELICTIS RESERVATIS Z 2010 ROKU
}

Treść: Wstęp. - 1. Przestępstwo molestowania seksualnego małoletniego. - 2. Przestępstwo pornografii dziecięcej. - Zakończenie.

\section{Wstęp}

Jedną z grup przestępstw zarezerwowanych Kongregacji Nauki Wiary w Normach De delictis reservatis z 2010 roku stanowią delicta graviora contra mores, czyli ciężkie przestępstwa przeciwko obyczajom. Mamy tutaj nawiązanie do przestępstw przeciwko szóstemu przykazaniu Dekalogu, o których w kan. $1395 \S \S$ 1-2 Kodeksu Prawa Kanonicznego z 1983 roku$^{1}$, oraz w kan. 1453 § 1 Kodeksu Kanonów Kościołów Wschodnich z 1990 roku² $^{2}$ Należy jednak podkreślić, że z szerokiej gamy przestępstw rozważanych w zacytowanych powyżej kanonach, do kategorii delicta reservata zostały włączone jedynie dwa

${ }^{1} \mathrm{KKP} / 1983$, kan. 1395: „§ 1. Duchowny konkubinariusz poza wypadkiem, o którym w kan. 1394, oraz duchowny trwający w innym grzechu zewnętrznym przeciwko szóstemu przykazaniu Dekalogu, wywołującym zgorszenie, winien być ukarany suspensą, do której, gdy mimo upomnienia trwa w przestępstwie, można stopniowo dodawać inne kary, aż do wydalenia ze stanu duchownego. $§ 2$. Duchowny, który w inny sposób wykroczył przeciwko szóstemu przykazaniu Dekalogu, jeśli jest to połączone z użyciem przymusu lub gróźb, albo publicznie lub z osobą małoletnią poniżej lat szesnastu, powinien być ukarany sprawiedliwymi karami, nie wyłączając w razie potrzeby wydalenia ze stanu duchownego".

${ }^{2}$ KKKW/1990, kan. 1453 § 1: „Duchowny konkubinariusz lub trwający w innym grzechu zewnętrznym przeciwko czystości wywołującym zgorszenie, powinien zostać ukarany suspensą, do której, gdy trwa w przestępstwie, można stopniowo dodawać inne kary aż do depozycji”. 
następujące rodzaje naruszeń szóstego przykazania Dekalogu: przestępstwo molestowania seksualnego małoletniego (z małoletnimi są tutaj zrównani także ci pełnoletni, którzy habitualnie posiadają niepełne używanie rozumu) oraz przestępstwo pornografii dziecięcej3 ${ }^{3}$. Normy De gravioribus delictis z 2001 roku do kategorii delictum contra mores zaliczały jedynie przestępstwo przeciwko szóstemu przykazaniu Dekalogu popełnione przez duchownego z małoletnim poniżej osiemnastego roku życia ${ }^{4}$. Aktualne Normy przewidują zatem szerszy zakres przestępstw contra mores, w przypadku których konieczna jest interwencja Kongregacji Nauki Wiary. Takie rozszerzenie zakresu kompetencji Kongregacji w sprawach delicta graviora contra mores wskazuje na to, z jak wielką troską Kościół podchodzi do kwestii ochrony dobrych obyczajów w tym, co się odnosi do zachowania szóstego przykazania Dekalogu. W sposób szczególny jest tutaj widoczna troska Kościoła o ochronę osób małoletnich oraz tych, które są z nimi zrównane przed ewentualnym wykorzystywaniem w celach lubieżnych, a zatem przed naruszeniem ich integralności fizycznej, psychicz-

3 Art. 6: „§ 1 Delicta graviora contra mores, Congregationi pro Doctrina Fidei cognoscendo reservata, sunt: $n$. 1 delictum contra sextum Decalogi praeceptum cum minore infra aetatem duodeviginti annorum a clerico commissum; in hoc numero minori aequiparatur persona quae imperfecto rationis usu habitu pollet; $2^{\circ}$ comparatio vel detentio vel divulgatio imaginum pornographicarum minorum infra aetatem quattuordecim annorum quovis modo et quolibet instrumento a clerico turpe patrata", CONGREGATIO PRo Doctrina FIDEI, Normae de delictis Congregationi pro Doctrina Fidei reservatis seu Normae de delictis contra fidem necnon de gravioribus delictis (21.05.2010), AAS 102 (2010), s. 424.

4 „Delictum contra mores, videlicet: delictum contra sextum Decalogi praeceptum cum minore infra aetatem duodeviginti annorum a clerico commissum", CongREGATIO Pro Doctrina FideI, Epistula a Congregatione pro Doctrina Fidei missa ad totius Catholicae Ecclesiae Episcopos aliosquae Ordinarios et Hierarchos interesse habentes: de delictis gravioribus eidem Congregationi pro Doctrina Fidei reservatis, 18 maii 2001, AAS 93 (2001), s. 787. Zob. G. NúÑEZ, La competencia penal de la Congregación para la Doctrina de la Fe. Comentario al m.p. Sacramentorum Sanctitatis Tutela, Ius Canonicum 53 (2003), s. 380-381; V. DE PAOLIs, Norme de gravioribus delictis riservati alla Congregazione per la Dottrina della Fede, Periodica 91 (2002), s. 308-309; D. BoreK, Ordynariusz a $<$ Delicta Graviora $>$ zarezerwowane Kongregacji Doktryny Wiary, Prawo Kanoniczne 47 (2004) 3-4, s. 125-128. 
nej i moralnej w sferze seksualności. Ponadto, należy zaznaczyć, że owa wola ochrony małoletnich i osób z nimi zrównanych przed nadużyciami w sferze szóstego przykazania Dekalogu jest widoczna także w wydłużeniu okresu przedawnienia actio criminalis oraz w rodzaju sankcji karnej przewidzianej za delicta graviora contra mores. Normy De delictis reservatis z 2010 roku wydłużyły okres przedawnienia skargi kryminalnej aż do dwudziestu lat, z zachowaniem prawa Kongregacji do uchylenia tego terminu ${ }^{5}$. Szczególny ciężar omawianych w artykule przestępstw wynika nie tylko z tego, że naruszenia szóstego przykazania Dekalogu dotyczą małoletnich i tych, którzy ze względu na stopień używania rozumu są z nimi zrównani, ale także i z tego, że sprawcami tych naruszeń są duchowni. $\mathrm{Z}$ tego też względu Normy $D e$ delictis reservatis z 2010 roku przewidują dla duchownego obowiązkową karę ferendae sententiae do zaaplikowania stosownie do ciężaru przestępstwa, nie wykluczając najcięższej z kar ekspiacyjnych wiążącej na stałe, czyli wydalenia lub depozycji ${ }^{6}$.

W niniejszym artykule analizie zostaną poddane jedynie te spośród delicta reservata, które dotyczą obyczajów: przestępstwo molestowania seksualnego małoletniego oraz przestępstwo pornografii dziecięcej.

\section{Przestępstwo molestowania seksualnego małoletniego}

Pierwszym z przestępstw należących do kategorii delicta graviora contra mores jest przestępstwo molestowania seksualnego małoletniego, tzn. przestępstwo przeciwko szóstemu przykazaniu Dekalogu popełnione przez duchownego z małoletnim poniżej osiemnastego roku życia

5 Art. 7: „§ 1. Salvo iure Congragationis pro Doctrina Fidei a praescriptionie derogandi pro singulis casibus, actio criminalis de delictis Congregationi pro Doctrina Fidei reservatis praescriptione exstinguitur spatio viginti annorum. $\S 2$. Praescriptio decurrit ad normam can. $1362 \S 2$ Codicis Iuris Canonici et can. $1152 \S 3$ Codicis Canonum Ecclesiarum Orientalium. In delicto autem, de quo in art. $6 \S 1 \mathrm{n}$. 1, praescriptio decurrere incipit a die quo minor duodevicesimum aetatis annum explevit", Congregatio pro Doctrina Fidei, Normae de delictis Congregationi pro Doctrina Fidei reservatis..., s. 424.

${ }^{6}$ Art. 6: „\$ 2 Clericus qui delicta de quibus in $\S 1$ patraverit, pro gravitate criminis puniatur, non exclusa dimissione vel depositione", Congregatio Pro Doctrina FideI, Normae de delictis Congregationi pro Doctrina Fidei reservatis..., s. 424. 
oraz z takim pełnoletnim, który habitualnie posiada niepełne używanie rozumu ${ }^{7}$. Do istotnych znamion omawianej formy przestępstwa należą następujące elementy: przestępstwo przeciwko szóstemu przykazaniu Dekalogu; małoletni oraz osoby z nimi zrównane jako podmioty bierne przestępstwa; duchowni jako podmioty czynne przestępstwa.

Przestępstwo, o którym mowa w Normach De delictis reservatis z 2010 roku, zostało zdefiniowane jako przestępstwo przeciwko szóstemu przykazaniu Dekalogu. Sformułowanie delictum contra sextum Decalogi praeceptum użyte na płaszczyźnie prawa karnego kanonicznego mogłoby się wydawać jednak nie dość precyzyjne ${ }^{8}$. Za takim stwierdzeniem przemawiałoby to, iż w świetle jednomyślnej nauki biblijnej przedmiotem szóstego przykazania jest zakaz dopuszczania się cudzołóstwa (por. Ez 20.14; Dt 5, 18), natomiast według tradycji kościelnej, z szóstym przykazaniem należy wiązać także i inne obowiązki ${ }^{9}$. Zgodnie $\mathrm{z}$ wymogiem ścisłej interpretacji ${ }^{10}$, naruszenie szóstego przykazania oznaczałoby wyłącznie naruszenie obowiązku dochowania wierności małżeńskiej i tego wszystkiego, co z niego wypływa. W tej perspektywie, delictum contra sextum Decalogi praeceptum odnosiłoby się jedynie do grzesznych relacji duchownego z osobą pozostającą w związku małżeńskim. Oczywiście taka interpretacja, w kontekście omawianego przestępstwa oraz w kontekście innych przestępstw w materii de sexto przewidzianych w Kodeksie Prawa Kanonicznego, wydaje się nieadekwatna ${ }^{11}$. Ustawodawca kościelny, po-

7 Art. 6: „§ 1 n. 1 delictum contra sextum Decalogi praeceptum cum minore infra aetatem duodeviginti annorum a clerico commissum; in hoc numero minori aequiparatur persona quae imperfecto rationis usu habitu pollet", CONGREGATIO PRO DoctRINA FIDEI, Normae de delictis Congregationi pro Doctrina Fidei reservatis..., s. 424.

8 Por. E. Miragoli, Il confessore e il "de sexto". Prospettiva giudica, Quaderni di Diritto Ecclesiale 4 (1991), s. 238-240.

9 Por. tamże, s. 239.

${ }^{10} \mathrm{KPK} / 1983$, kan. 18.

${ }^{11}$ Bardziej precyzyjne wydaje się sformułowanie użyte w Kodeksie Kanonów Kościołów Wschodnich. Otóż wspominany Kodeks, zamiast o grzechach przeciwko szóstemu przykazaniu, mówi o grzechach przeciwko czystości, a więc posługuje się terminem, który w kontekście biblijnego ujęcia treści szóstego przykazania, jest o wiele obszerniejszy, zob. KKKW/1990, kann. $728 \S 1$, n. 2º 730; 731; 1454; 1457. 
sługując się sformułowaniem sextum Decalogi praeceptum w kontekście przestępstw wyraźnie odnosi się do szerszego, zgodnego z tradycją kościelną, rozumienia treści szóstego przykazania Dekalogu ${ }^{12}$. Dlatego też należy uznać, że sformułowanie przestępstwo przeciwko szóstemu przykazaniu Dekalogu odnosi się do wszystkich czynów natury seksualnej będących naruszeniem treści zawartej w szóstym przykazaniu Dekalogu, a więc do naruszeń związanych z cnotą czystości ${ }^{13}$. Normy De delictis reservatis z 2010 roku mówiąc o delictum contra sextum Decalogi praeceptum odnoszą się zatem do wszystkich możliwych form molestowania seksualnego, obejmujących swoim zakresem różne rodzaje zachowań, począwszy od pokazywania materiałów pornograficznych i różnych niestosownych komentarzy, poprzez dotyki czy

\footnotetext{
${ }^{12}$ Sformułowanie sextum praeceptum Decalogi pojawia się w związku z takimi przestępstwami jak: rozgrzeszenie wspólnika w grzechu przeciw szóstemu przykazaniu Dekalogu (kann. 977; 1378 § 1); nakłanianie penitenta do grzechu przeciw szóstemu przykazaniu Dekalogu (kan. 1387); duchowny trwający w innym grzechu zewnętrznym przeciwko szóstemu przykazaniu Dekalogu (kan. 1395 § 1); duchowny, który w inny sposób wykroczył przeciwko szóstemu przykazaniu Dekalogu (kan. 1395 § 2). We wszystkich cytowanych kanonach mamy wyraźne odniesienie do różnych możliwych form wykroczenia przeciw szóstemu przykazaniu Dekalogu, a nie jedynie do cudzołóstwa. Ponadto sformułowanie sextum praeceptum Decalogi pojawia się konsekwentnie zarówno w Normach De gravioribus delictis z 2001 roku jak i w Normach De delictis reservatis z 2010 roku. Także w doktrynie mówi się o przestępstwach przeciwko szóstemu przykazaniu Dekalogu: V. De Paolis, Delitti contro il sesto comandamento, Periodica 82 (1993), s. 293-316; J.H. Provost, Offenses against the sixth commandment: toward a canonical analysis of canon 1395, The Jurist 55 (1995), s. 632-663; Z. SucheCKI, Przestęstwa przeciwko szóstemu przykazaniu dekalogu z uwzględnieniem ustaw partykularnych Konferencji Episkopatu USA, w: Powołanie franciszkańskie: przeżywanie charyzmatu w XXI wieku (red. Z. Kijas) Kraków 2003, s. 37-65; J. BeRnAL, Regulación de los "delitos contra el sexto mandamiento". El c. 1395, Fidelium Iura 13 (2003), s. 49-70; J. Bernal, Régimen vigente de los delitos contra el $6^{\circ}$ mandamiento, w: Processo penale e tutela dei diritti nell'ordinamento canonico, a cura di Davide Cito, Milano 2005, s. 415-432.

${ }^{13}$ Por. Z. Suchecki, Przestępstwa przeciwko szóstemu przykazaniu dekalogu..., s. 48. W tej perspektywie grzeszne relacje duchownego z osobą pozostającą w związku małżeńskim można uznać za naruszenie szóstego przykazania Dekalogu w sensie ścisłym, por. J.H. Provost, Some canonical considerations relative to clerical sexual misconduct, The Jurist 52 (1992), s. 655.
} 
pocałunki często powtarzane, a skończywszy na kontakcie cielesnym czy wręcz pełnej penetracji seksualnej. Przestępstwem molestowania będzie także dokonywanie aktów seksualnych na samym sobie przez duchownego w obecności małoletniego ${ }^{14}$. Dla zaistnienia omawianej formy przestępstwa nie będzie miało znaczenia to, czy będzie to molestowanie bezpośrednie, a więc kontakt fizyczny, czy też molestowanie pośrednie $^{15}$. Wystarczy tutaj bowiem, aby z działania podjętego przez sprawcę wynikał zamiar wykorzystania małoletniego w celu uzyskania podniety seksualnej, czy zaspokojenia seksualnego ${ }^{16}$. Dla zaistnienia przestępstwa nie będzie miało znaczenia także i to, czy będzie to czyn jednorazowy, czy zachowanie habitualne ${ }^{17}$.

W tym co się odnosi do podmiotów biernych przestępstwa molestowania seksualnego należy zaznaczyć, że Kościół w Normach De

${ }^{14}$ Por. C. PAPAle, I delitti contro la morale, w: Questioni attuali di diritto penale canonico, Studi Giuridici XCVI Città del Vaticano 2012, s. 57. Zob. E. PArolari, Aspetti psicopatologici dei delitti canonici, w: Questioni attuali di diritto penale canonico, Studi Giuridici XCVI Città del Vaticano 2012, s. 69.

${ }^{15}$ Por. Ch.J. Scicluna, Procedura e prassi presso la Congregazione per la Dotrina della Fede riguardo ai delicta graviora, w: Processo penale e tutela dei diritti nell'ordinamento canonico, pod red. D. Cito, Milano 2005, s. 282-283.

${ }^{16}$ D. Albornoz, Norme e orientamenti della Chiesa cattolica dinanzi agli abusi sessuali di minori perpetrati da chierici, Salesianum 70 (2008), s. 714-715.

${ }^{17}$ To rozróżnienie będzie ewentualnie mogło mieć znaczenie w kwestii przedawnienia actio criminalis (kan. 1362) i to jedynie w przypadku przestępstwa molestowania seksualnego osób pełnoletnich, ale zrównanych z małoletnimi, a więc tych pełnoletnich, którzy habitualnie posiadają niepełne używanie rozumu. W przypadku bowiem przestępstwa molestowania seksualnego małoletnich przedawnienie liczy się od dnia, w którym osoby takie uzyskają pełnoletność, niezależnie od tego czy mamy tutaj do czynienia z przestępstwem jednorazowym czy habitualnym, Art. 7: $§ 2, \ldots$ praescriptio decurrere incipit a die quo minor duodevicesimum aetatis annum explevit", Congregatio pro Doctrina Fidei, Normae de delictis Congregationi pro Doctrina Fidei reservatis..., s. 424. Natomiast w przypadku przestęptwa molestowania seksualnego pełnoletnich, ale zrównanych z małoletnimi, przedawnienie należy liczyć zgdnie z kan. 1362. Tak więc w przypadku przestępstwa jednorazowego przedawnienie liczy się od dnia popełnienia przestępstwa, a w przypadku przestępstwa permanentnego lub habitualnego od dnia jego ustania. Oczywiście z zachowaniem prawa Kongregacji do uchylenia terminu dwudziestu lat przedawnienia przewidzianego dla przestępstw jej zarezerwowanych. 
delictis reservatis z 2010 roku, mając na uwadze szczególny ciężar przestępstw w tej materii, otacza szczególną ochroną osoby zarówno ze względu na wiek, jak i stan używania rozumu. Podobnie jak Normy De gravioribus delictis z 2001 roku, tak samo aktualnie obowiązujące Normy De delictis reservatis uznają za przestępstwo naruszenie szóstego przykazania Dekalogu dokonane przez duchownego z małoletnim poniżej osiemnastego roku życia ${ }^{18}$. Elementem decydującym o popełnieniu omawianej formy przestępstwa jest jedynie wiek ofiar molestowania seksualnego, czyli nieukończony osiemnasty rok życia. Dla zaistnienia omawianej formy przestępstwa bez znaczenia jest to, czy będziemy mieli do czynienia z aktami pedofili w sensie ścisłym, czy efebofilii ${ }^{19}$. Tak więc, w myśl aktualnie obowiązującego prawa kanonicznego przestępstwem będzie jakiekolwiek wykroczenie przeciwko szóstemu przykazaniu Dekalogu dokonane przez duchownego z osobą, która nie ukończyła jeszcze osiemnastego roku życia ${ }^{20} \mathrm{i}$ to nie-

\footnotetext{
${ }^{18}$ Mamy tutaj zatem odejście od tego, co w kwestii przestępstwa molestowania seksualnego małoletnich przewiduje KPK/1983 roku w kan. 1395 § 2. Zgodnie, bowiem z zacytowanym kanonen przestępstwo popełnia duchowny, który wykracza przeciwko szóstemu przykazaniu Dekalogu z małoletnim poniżej szesnastego roku życia. Jeszcze niższą barierę wieku ofiar przestępstw seksualnych przewiduje polskie prawo karne. Zgodnie bowiem z art. 200 Kodeksu Karnego: „§ 1. Kto doprowadza małoletniego poniżej 15 lat do obcowania płciowego lub do poddania się innej czynności seksualnej, albo do wykonania takiej czynności, podlega karze pozbawienia wolności od roku do lat 10. $\S 2$. Tej samej karze podlega, kto utrwala treści pornograficzne z udziałem takiej osoby". Według prawodawcy państwowego obcowanie z osobą powyżej piętnastego roku życia nie jest już przestępstwem, zob. J. WARYLEWSKI, Przestępstwa przeciwko wolności seksualnej i obyczajowości. Rozdziat XXV Kodeksu karnego. Komentarz, Warszawa 2001, s. 151-152.

${ }^{19} \mathrm{~W}$ przypadku pedofilii chodzi o nadużycia seksualne popełnione w stosunku do dzieci przed pokwitaniem (aż do 13 roku życia), natomiast w przypadku efebofilii chodzi o nadużycia seksualne w stosunku do małoletnich pomiędzy 14 a 17 rokiem życia, por. E. Parolari, Aspetti psicopatologici..., s. 69; G. Versaldi, Aspetti psicologici degli abusi sessuali perpetrati da chierici, Periodica 91 (2002), s. 49-61. Więcej na temat definicji psychiatrycznej pedofilii zob. T. WYTRWAŁ, Kościelny modus procedendi w przypadku pedofilii, Prawo Kanoniczne 52 (2009) n. 1-2, s. 233-235.

${ }^{20}$ T. Wytrwat, Kościelny modus procedendi..., s. 237; D. Albornoz, Norme e orientamenti della Chiesa cattolica..., s. 714-715.
} 
zależnie od płci takiej osoby małoletnieje' ${ }^{21}$ oraz jej postawy. W związku z powyższym nie będzie tutaj miało znaczenia to, czy osoba będąca przedmiotem wykroczeń przeciwko szóstemu przykazaniu Dekalogu dobrowolnie i spontanicznie zgadza się na dany czyn seksualny, czy też sama go sprowokowała, lub czy też wszystko odbyło się wbrew jej woli ${ }^{22}$. Można sobie zadać jednak pytanie, czy małoletni pomiędzy szesnastym a osiemnastym rokiem życia, w przypadku omawianego przestępstwa, mógłby odpowiadać na zasadach, o których w kan. 1329, przykładowo w przypadku, gdyby do grzechu doszło z inicjatywy takiego małoletniego. Powyższe pytanie mogłoby się wydawać uzasadnione, biorąc pod uwagę fakt, iż zdecydowana większość stwierdzonych przypadków molestowania seksualnego małoletnich to przypadki efebofilii ${ }^{23}$. Na postawione pytanie należy udzielić jednak odpowiedzi negatywnej, gdyż podniesienie wieku ofiar molestowania seksualnego do osiemnastu lat oznacza, że małoletni, niezależnie od ich postawy zostali uznani za ofiary przestępstwa nadużyć seksualnych, a nie za ewentualnych wspólników takiego przestępstwa.

Nowością, w zakresie podmiotów biernych omawianego przestępstwa, wprowadzoną przez Normy De delictis reservatis z 2010 roku, jest zrównanie z osobą małoletnią osoby, która habitualnie posiada niepełne używanie rozumu. Dwie rzeczy wymagają tutaj podkreślenia. Po pierwsze

${ }^{21}$ Por. J. SyRYJCZYK, Kanoniczne prawo karne, część szczególna, Warszawa 2003, s. 165.

${ }^{22}$ Por. C. Papale, I delitti contro la morale..., s. 55-56.

${ }^{23}$ Jak wynika z relacji CH. J. SciclunA, promotora sprawiedliwości w Kongregacji Nauki Wiary, w zdecydowanej większości przypadków omawianego przestępstwa, mamy do czynienia z aktami efebofilii. W latach 2001 - 2010 zostało doniesionych do Kongregacji Nauki Wiary około trzech tysięcy przypadków nadużyć seksualnych dokonanych przez duchownych w ostatnich pięćdziesięciu latach. Sześćdziesiąt procent przypadków dotyczyło aktów efebofilii, będących wynikiem pociągu seksualnego w stosunku do małoletnich osób tej samej płci. Trzydzieści procent dotyczyło raportów heteroseksualnych. I w końcu dziesięć procent dotyczyło pedofilii we właściwym tego słowa znaczeniu, czyli aktów będących wynikiem pociągu seksualnego w stosunku do dzieci. Tak więc, biorąc pod uwagę ogólną liczbę przypadków, które zostały przedstawione w Kongregacji, duchownych oskarżonych o prawdziwą pedofilię było około trzystu, por. G. CuCCI - H. Zollner, Chiesa e pedofilia. Una ferita aperta. Un approccio psicologico-pastorale, Venezia 2010, s. 23. 
nie wymaga się, aby osoba, która jest ofiarą molestowania seksualnego była całkowicie pozbawiona używania rozumu. Do zaistnienia przestępstwa wystarczy bowiem, że u osoby będącej ofiarą tego przestępstwa normalne procesy intelektualne i wolitywne będą przynajmniej częściowo naruszone. Po drugie należy zaznaczyć, że ten stan niepełnego używania rozumu nie może być stanem przejściowym, ale musi posiadać charakter trwały, nawet jeżeli zdarzają się tzw. lucida intervalla. Nie będzie można zatem mówić o popełnieniu omawianego przestępstwa, jeżeli podmiotem biernym molestowania seksualnego będzie osoba, która w momencie molestowania posiadała niepełne używanie rozumu, wynikające z przyczyn o charakterze przejściowym (np. nadużycie alkoholu) ${ }^{24}$. Do popełnienia omawianej formy przestępstwa wystarczy, że osoba będącą przedmiotem molestowania, według opinii biegłych habitualnie posiada niepełne używanie rozumu, niezależnie od przyczyn takiego stanu ${ }^{25}$.

Jak wynika z dyspozycji zawartej w Normach De delictis reservatis z 2010 roku, sprawcą omawianego przestępstwa może być jedynie duchowny ${ }^{26}$. Mamy tutaj zatem do czynienia z delicta propria, a więc z przestępstwami właściwymi pewnej kategorii osób w Kościele, tzn. z takimi, których sprawcą może być określony krąg osób. W omawianym przypadku będą to jedynie ci, którzy przyjęli święcenia ${ }^{27}$ : diako$\mathrm{ni}^{28}$, prezbiterzy i biskupi ${ }^{29}$. W pojęciu duchownego nie mieszczą się

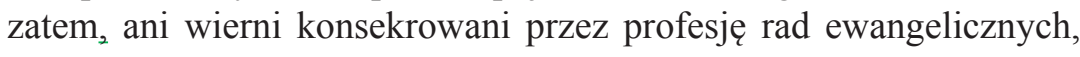

${ }^{24}$ Por. C. Papale, I delitti contro morale ..., s. 56.

${ }^{25}$ Por. tamże, s. 56-57.

${ }^{26}$ Art. 6: ,§ 1 n. 1 delictum contra sextum Decalogi praeceptum cum minore infra aetatem duodeviginti annorum a clerico commissum; in hoc numero minori aequiparatur persona quae imperfecto rationis usu habitu pollet", CONGREGATIO PRO DoctRINA FIDEI, Normae de delictis Congregationi pro Doctrina Fidei reservatis..., s. 424.

${ }^{27}$ Zob. KPK/1983, kann. 266 § 1, 1009 § 1.

${ }^{28}$ Będzie chodziło tutaj zarówno o diakonów do prezbiteratu jak i o diakonów stałych, zob. KPK/1983, kann. 236, 1031 § 2, 1032 § 3.

${ }^{29}$ Por. C. PAPAle, I delitti contro la morale..., s. 55. 
którzy nie przyjęli święceń ${ }^{30}$, ani tym bardziej wierni świeccy ${ }^{31}$. Pozostając w zgodzie z kan. 18 KPK/1983, który domaga się zastosowania ścisłej interpretacji ustaw karnych, należy stwierdzić, że Normy De delictis reservatis z 2010 roku nie mają zastosowania w przypadku, gdyby wykroczenia przeciwko szóstemu przykazaniu Dekalogu z osobą małoletnią dopuścił się zakonnik, który nie posiada święceńn ${ }^{32}$, albo wierny świecki, np. pełniący jakąś misję w imieniu Kościoła.

Podsumowując, należy stwierdzić, że w omawianej formie przestępstwa będzie chodziło o wszelkie formy molestowania seksualnego popełnione przez duchownego wobec osoby poniżej osiemnastego roku życia, lub wobec osoby, która habitualnie posiada niepełne używanie rozumu. Molestowanie seksualne staje się bowiem szczególnie ciężkie wtedy, kiedy dotyczy osób, które, ze względu na wiek lub używanie rozumu, nie mają wolności wyrażenia prawnej i pełnej zgody. $\mathrm{Z}$ tego powodu, osoby nieletnie lub ci, którzy w sensie psychicznym zachowują się jak osoby nieletnie i bezbronne, ponoszą największy uszczerbek na zdrowiu psychicznym. Takie przestępstwa zasługują na najsurowsze konsekwencje, tym bardziej, jeżeli nadużycia seksualne zostały popełnione przez duchownych na dzieciach lub młodzieży powierzonych bezpośrednio ich opiece. Główną wartością, jaką chronią powyższe dyspozycje jest bowiem ochrona osób małoletnich oraz osób z nimi zrównanych, a dokładnie ich integralności fizycznej, psychicznej i moralnej ${ }^{33}$. Należy jednak podkreślić, że według przepro-

${ }^{30}$ Sposób postępowania w przypadku duchownych zakonników, którzy dopuściliby się któregoś z omawianych w artykule przestępstw, winien uwzględniać normy proceduralne przewidziane w przypadku delicta reservata, $\mathrm{z}$ uwzględnieniem wewnętrznej struktury procedowania, zob. CH.J. SciclunA, Procedura e prassi presso la Congregazione per la Dotrina della Fede..., s. 286-288.

${ }^{31}$ Zob. KPK/1983, kan. 207.

${ }^{32} \mathrm{~W}$ takich przypadkach kompetentny Ordynariusz winien postępować zgodnie z ogólnymi wytycznymi. Aktualnie obowiązujący Kodeks Prawa Kanonicznego uwzględnia przestępstwa w materii de sexto dokonane przez zakonników, członków instytutów świeckich i stowarzyszeń życia apostolskiego w następujących kanonach: 695, 729, 746.

${ }^{33}$ Szczególny ciężar takiego grzechu wynika z gorszącego zamachu na integralność fizyczną i moralną młodych, którzy będą nosić jego piętno przez całe życie. Jeszcze 
wadzonych analiz, problem pedofilii wśród duchowieństwa, czy osób konsekrowanych nie jest wcale wyższy aniżeli wśród innych grup społecznych, tym samym nie można go łączyć bezpośrednio z celibatem kapłańskim, czy zakonnym ślubem czystości ${ }^{34}$. Niezależnie od powyższego stwierdzenia, należy podkreślić, że przestępstwo seksualnego wykorzystania małoletnich, czy to pod postacią pedofilii, czy też efebofilii, to jeden z najpoważniejszych problemów z jakimi musiał się zmierzić Kościół w ostatnich czasach ${ }^{35}$.

\section{Przestępstwo pornografii dziecięcej}

Zgodnie z Normami De delictis reservatis z 2010 roku, do kategorii delicta graviora contra mores należy także przestępstwo pornografii dziecięcej. Przestępstwo pornografii, zgodnie z tym, co się postanawia w cytowanych Normach, może polegać albo na nabywaniu, albo na przechowywaniu, albo też na rozpowszechnianiu w celach lubieżnych

poważniejszy jest gwałt popełniony przez rodziców lub wychowawców na dzieciach, które są im powierzone (KKK, n. 2356). Takie działania rodziców i wychowawców stanowią ponadto pogwałcenie odpowiedzialności wychowawczej, jaka na nich spoczywa (KKK, n. 2389).

${ }^{34}$ Por. G. CucCI - H. Zollner, Chiesa e pedofilia..., s. 36. Jak zauważa E. Parolari, nie istnieje jakieś szczególne połączenie pomiędzy celibatem a pedofilią, czego dowodem jest fakt, iż zdecydowana większość molestowań małoletnich ma miejsce w kontekście rodzinnym (jest od 84 do 90 procent przypadów) a w 27 procentach dotyczy to najbliższych członków rodziny (kazirodztwo), E. PArolari, Aspetti psicopatologici..., s. 69.

${ }^{35} \mathrm{Na}$ temat rozmiarów tego problemu oraz reakcji Kościoła zob. C. CAMPONI, $L a$ tutela penale del minore nell'ordinamento canonico con particolare riferimento alla fattispecie sub can. 1395 \& 2, Roma 2003, s. 38-41; D. Albornoz, Norme e orientamenti della Chiesa cattolica..., s. 711-726; G. MARCHESI, La Chiesa Cattolica negli Stati Uniti scossa dallo scandalo della pedofilia, La Civiltà Cattolica 153 (2002) II, s. 477-486. Bardzo często media nadają rozgłosu tego rodzaju sprawom przyczyniając się w ten sposób niesłusznie do wyolbrzymienia problemu, podczas gdy zjawisko dotyczy niewielu konkretnych przypadków. Niemniej jednak, głównie ze względu na szczególną krzywdę, jakiej doznają ofiary tych przestępstw, jest to problem najwyższej wagi, którego nie można zbagatelizować, zob. E. ConwAY, Le teologie operative del sacerdotio hanno contribuito agli abusi sessuali sui minori?, Concilium 49 (2004) z. 3, s. 103-107; G. CREA - G.F. Pol, Abuso sessuale e vita religiosa, Vita Consacrata 39 (2003), s. 297. 
obrazów pornograficznych z małoletnimi poniżej czternastego roku życia, dokonanym przez duchownego w jakikolwiek sposób i przy użyciu jakiegokolwiek instrumentu ${ }^{36}$. Do istotnych znamion omawianego obecnie przestępstwa contra mores należą następujące elementy: pornografia dziecięca; cel lubieżny; duchowny jako podmiot aktyny.

Katechizm Kościoła Katolickiego podaje następujące określenie pornografii: „Pornografia polega na wyrywaniu aktów płciowych, rzeczywistych lub symulowanych, z intymności partnerów, aby w sposób zamierzony pokazywać je innym. Znieważa ona czystość, ponieważ stanowi wynaturzenie aktu małżeńskiego, wzajemnego intymnego daru małżonków. Narusza poważnie godność tych, którzy się jej oddają (aktorzy, sprzedawcy, publiczność), ponieważ jedni stają się dla drugich przedmiotem prymitywnej przyjemności i niedozwolonego zarobku. Przenosi ona ich wszystkich w świat iluzoryczny. Pornografia jest ciężką winą. Władze cywilne powinny zabronić wytwarzania i rozpowszechnienia materiałów pornograficznych" "37. Pod pojęciem pornografii dziecięcej możemy zatem rozumieć wszelkiego rodzaju obrazy, a więc zdjęcia lub wideo, zawierające akty seksualne z małoletnimi, poniżej czternastego roku życia, albo pomiędzy takimi małoletnimi, lub też zawierające obrazy ww. małoletnich w pozycjach lub zachowaniach zmierzających do wywołania zainteresowania (pobudzenia) seksualnego u osób oglądających te obrazy ${ }^{38}$. Należy jednak podkreślić, że do kategorii delicta reservata należy tylko ta pornografia, która dotyczy małoletnich poniżej 14 roku życia. To kryterium wieku ofiar pornografii może być w praktyce bardzo trudne do weryfikacji. Jak zauważa D.G. Astigueta, ustalenie wieku osób znajdujących się na ma-

${ }^{36}$ Art. 6: , $\S 1$, n. $2^{\circ}$ comparatio vel detentio vel divulgatio imaginum pornographicarum minorum infra aetatem quattuordecim annorum quovis modo et quolibet instrumento a clerico turpe patrata", Congregatio pro Doctrina Fidei, Normae de delictis Congregationi pro Doctrina Fidei reservatis..., s. 424.

${ }^{37}$ KKK, n. 2354.

${ }^{38}$ Por. C. PAPAle, I delitti contro la morale..., s. 59; D.G. Astigueta, Ultime modifiche al motu proprio delicta graviora, w: Il quindicesimo anniversario dell'istituto di diritto canonico "Ad instar facultatis" dell’Università Cattolica Pázmány Péter, red. Sz. Anzelm Szuromi, Budapeszt 2011, s. 80. 
teriałach pornograficznych nie będzie łatwe, oczywiście za wyjątkiem małych dzieci. Ponadto, według tegoż samego autora, nie bardzo zrozumiałe wydaje się ustalenie górnej granicy wieku w postaci czternastego roku życia. Tak samo złe są przecież materiały pornograficzne dotyczące małoletnich w wieku lat piętnastu, jak i tych w wieku lat trzynastu. Być może byłoby lepiej użyć tutaj tego samego kryterium co w przypadku przestępstwa molestowania małoletnich, więc osiemnastego roku życia ${ }^{39}$. Ponadto należy podkreślić, że musimy tutaj mieć do czynienia z takimi zdarzeniami, które rzeczywiście miały miejsce. W przypadkach tzw. pornografii dziecięcej wirtualnej, a więc będącej efektem zabiegów technicznych i graficznych, nie będzie można mówić o przestępstwie ${ }^{40}$.

Zgodnie z Normami De delictis reservatis z 2010 roku omawiane przestępstwo może polegać albo na nabywaniu, albo na przechowywaniu, albo na rozpowszechnianiu treści pornograficznych dotyczących małoletnich poniżej czternastego roku życia. Pierwsze z wyliczonych działań to comparatio, czyli sytuacja, kiedy ktoś nabywa od osób trzecich, np. poprzez Internet, materiały zawierające pornografię dziecięcą. Do zaistnienia przestępstwa osoba musi mieć świadomość, że nabywa materiał z pornografią dziecięcą i musi tego chciećc1 ${ }^{4}$ Drugie z wyliczonych działań to detentio, czyli przechowywanie materiałów z pornografią dziecięcą. Oczywiście ta forma przestępstwa może być następstwem nabycia dokonanego, w sposób świadomy, ale może się także zdarzyć, że będzie ona wynikiem nieświadomego nabycia. Może się bowiem, zdarzyć, że osoba nieświadomie nabędzie materiały z pornografią dziecięcą, ale po ich zobaczeniu zachowuje je w celach lubieżnych ${ }^{42}$. Istotnym znamieniem tej formy przestępstwa jest

\footnotetext{
${ }^{39}$ Por. D.G. Astigueta, Ultime modifiche al motu proprio..., s. 81.

${ }^{40}$ C. PAPAlE, I delitti contro la morale..., s. 63.

${ }^{41}$ Tamże, s. 59-61.

${ }^{42}$ Może to mieć miejsce w przypadku browsing, który może być niezamierzony. Natomiast w przypadku down-loading trudno byłoby mówić o charakterze nieświadomym i niezamierzonym takiego działania. W tym ostanim przypadku bowiem nie tylko, że wymagane jest dokonanie określonego wyboru, ale ponadto bardzo często są to usługi odpłatne za pośrednictwem karty kredytowej, wymagające podania danych osobisty-
} 
to, że określony materiał pornograficzny jest do dyspozycji na każde żądanie, czego sprawca jest świadomy ${ }^{43}$. Ostatnia $\mathrm{z}$ form omawianego przestępstwa to divulgatio, czyli rozpowszechnianie materiału z pornografią dziecięcą. Do zaistnienia tej formy przestępstwa jest konieczne, aby sprawca był w posiadaniu takiego materiału i następnie podjął działania umożliwiające udostępnienie (tytułem odpłatnym lub bezpłatnie) tych materiałów osobom trzecim (czy to jednej osobie, czy też większej licznie osób), aby mogły z nich korzystać ${ }^{44}$.

Przestępstwo pornografii dziecięcej należy uznać za dokonane, oczywiście przy obecności pozostałych znamion o których będzie mowa poniżej, już wtedy, kiedy będzie miało miejsce albo samo nabywanie, albo samo przechowywanie, albo samo rozpowszechnianie. Do popełnienia przestępstwa wystarczy bowiem dopuszczenie się jednego z wyliczonych działań. Jeżeli natomiast jedna i ta sama osoba dopuści się wszystkich trzech form, a więc będzie nabywała, przechowywała i rozpowszechniała, to jednak nie będzie można mówić o trzech różnych przestępstwa, ale o jednym, chociaż o większym ciężarze ${ }^{45}$. Normy De delictis reservatis z 2010 roku przewidując różne sposoby popełnienia przestępstwa pornografii dziecięcej nie określają jednak rodzaju instrumentów technicznych, przy użyciu których może dojść do ich realizacji. Nie ulega wątpliwości, że jednym z możliwych instrumentów jakiego dostarcza współczesna technika jest Internet ${ }^{46}$.

ch nabywającego. W tych przypadkach nabywający raczej nie pzostaje anonimowy i często zostaje wykryty. Zdarzało się, że niektórzy kapłani byli skazywani właśnie za posiadanie tysięcy fotografii pornograficznych dotyczących dzieci, Z. SUCHECKI, $L a$ tutela penale dei minori presso la Congragazione per la Dottrina della Fede riguardo ai delicta graviora, Apollinaris 79 (2006), s. 723-724.

${ }^{43}$ C. Papale, I delitti contro la morale..., s. 61-62.

${ }^{44}$ Tamże, s. 62-63.

${ }^{45}$ Por. A. Calabrese, Diritto penale canonico, Città del Vaticano 1996, s. 274; B. F. Pighin, Diritto penale canonico, Venezia 2008, s. 335-336; J. Syry Jczyk, Kanoniczne prawo karne..., s. 50-51; G. URRU, Punire per salvare. Il sistema penale nella chiesa, Roma 2002, s. 198.

${ }^{46}$ Szerzej na temat problematyki wykorzystania Internetu dla dokonania omawianego przestępstwa zob. C. PAPALE, I delitti contro la morale..., s. 58-59. 
Istotnym znamieniem wszystkich form omawianego przestępstwa jest wina umyślna specyficzna po stronie osoby nabywającej, lub przechowującej, lub też rozpowszechniającej treści pornograficzne z małoletnimi poniżej czternastego roku życia. Należy podkreślić, że do zaistnienia omawianego przestępstwa musi mieć miejsce dolus specificus. Nie wystarczy zatem, aby sprawca działał świadomie i dobrowolnie, ale konieczny jest cel specyficzny takiego działania. Wskazuje na to użyte w normach sformułowanie a clerico turpe patrata - każde z wyliczonych działań, chociaż posiada różny ciężar, winno być zatem dokonane przez duchownego w celach lubieżnych ${ }^{47}$. Do zaistnienia omawianego przestępstwa nie wystarczy przykładowo samo posiadanie wspominanych materiałów pornograficznych, konieczne jest jeszcze, aby to posiadanie motywowane było celami lubieżnymi. Konieczność udowodnienia owego celu specyficznego to dodatkowy wymóg stwierdzenia popełnienia omawianej formy przestępstwa ${ }^{48}$.

Podmiotem aktywnym omawianego przestępstwa jest tylko duchowny. Mamy tutaj do czynienia, podobnie jak w przypadku przestępstwa molestowania seksualnego małoletniego, z delicta propria, a więc z przestępstwami właściwymi pewnej kategorii osób w Kościele, tzn. z takimi, których sprawcą może być określony krąg osób. W omawianym przypadku jedynie ci, którzy przyjęli święcenia diakonatu, prezbiteratu lub episkopatu ${ }^{49}$. Nie jest tutaj jednak wykluczona realna możliwość pociągnięcia do odpowiedzialności karnej także ewentualnych wspólników przestępstwa w myśl dyspozycji jaką znajdujemy w kan. 1329. Szczególnie dotyczyć to będzie nabywania i rozpowszechniania pornografii dziecięcej, które to działania z natury swojej wymagają wspólnika (partnera).

\section{Zakończenie}

Normy De delictis reservatis z 2010 roku w części poświęconej normom substancjalnym bazują wprawdzie na tym, co zostało wpro-

\footnotetext{
${ }^{47}$ Por. tamże, s. 64-65.

${ }^{48}$ Por. D.G. Astigueta, Ultime modifiche al motu proprio..., s. 81.

${ }^{49}$ Por. C. PAPALE, I delitti contro la morale..., s. 59.
} 
wadzone w Normach De gravioribus delictis z 2001 roku, niemniej jednak w tym, co się odnosi do poszczególnych przestępstw zarezerwowanych Kongregacji Nauki Wiary wprowadzają istotne zmiany i innowacje. Na szczególną uwagę zasługują zmiany wprowadzane $\mathrm{w}$ materii delicta graviora contra mores. Aktualnie obowiązujące Normy wprowadzają dwie istotne zmiany w kategorii przestępstw dotyczących obyczajów. Po pierwsze, do przestępstwa polegającego na naruszeniu szóstego przykazania Dekalogu dokonanego przez duchownego z małoletnim poniżej osiemnastego roku życia dodano także analogiczne naruszenia dokonane przez duchownego z osobą pełnoletnią, ale która habitualnie posiada niepełne używanie rozumu. Po drugie dodano tzw. przestępstwo pornografii dziecięcej, polegające albo na nabywaniu, albo na przechowywaniu, albo na rozpowszechnianiu w celach lubieżnych obrazów pornograficznych z małoletnimi poniżej czternastu lat, dokonanym przez duchownego w jakikolwiek sposób i przy użyciu jakiegokolwiek instrumentu.

Zmiany, jakie zostały wprowadzone przez Normy z 2010 roku w materii przestępstw zarezerwowanych Kongregacji Nauki Wiary dotyczące obyczajów, wskazują na to, z jak wielką troską Kościół podchodzi nie tylko do kwestii ochrony czystości obyczajów w tym, co się tyczy szóstego przykazania, ale także do ochrony małoletnich oraz osób z nimi zrównanych przed ewentualnymi nadużyciami w sferze seksualności. Szczególny ciężar przestępstwa molestowania seksualnego oraz pornografii dziecięcej wynika nie tylko z faktu naruszenia szóstego przykazania Dekalogu, ale przede wszystkim z gorszącego zamachu na integralność fizyczną, psychiczną i moralną małoletnich i sób z nimi zrównanych, które będą nosić jego piętno przez całe życie. Stąd też wymóg interwencji kompetentnej władzy kościelnej w celu pociągnięcia do odpowiedzialności karnej, nie wykluczając najsurowszej kary ekspiacyjnej wydalenia ze stanu duchownego, tych duchownych którzy mieliby nieszczęście dopuścić się któregoś z wyżej omówionych przestępstw. 


\section{Delicta graviora contra mores in De delictis reservatis Norms from 2010}

The present article analyses delicta graviora contra mores, that is the crimes reserved to the Congregation for the Doctrine of the Faith in De delictis reservatis Norms from 2010 concerning morals, namely sexual abuse of minors, as well as child pornography.

The first of the crimes contra mores is sexual abuse committed by a cleric with regard to minors and other subjects with permanently imperfect use of reason. It comprises all the forms of sexual abuse, ranging from showing pornographic materials, uttering improper comments, through inappropriate touching or kissing, to a physical contact or even a full sexual penetration. Such crimes deserve the strictest consequences, especially when they are committed by clergy towards children or youth entrusted in their custody.

The latter category of crimes discussed in this article is the one of child pornography which is, according to De delictis reservatis Norms from 2010, purchasing, storing and distributing for indecent purposes pornographic pictures with minors under fourteen years of age done by a cleric in any way and using any instruments. Pornography is an internally immoral act, especially in the case of child pornography, and one should not be surprised that the discussed crime has been classified into the delicta reservata category. Both of the crimes discussed in the article are the cases of so called delicta propria, that is the crimes whose offenders may be only clergy, which does not exclude a possibility of penal responsibility of potential co-offenders, according to the rules stated in Canon 1329.

Summing up, it should be stated that both keeping the existing instructions in the delicta graviora contra mores matter and introducing some changes and innovations indicate great concern of the Church for the protection of morals in regard to the sixth commandment of the Decalogue. Particularly important becomes visible concern of the Church for the protection of minors and subjects legally equal to them against any form of sexual abuse.

(Tłu. Ewa Walaszczyk)

SŁoWA KLUCZOWE: ciężkie przestępstwa, delicta reservata, molestowanie seksualne, małoletni, pornografia dziecięca, Kongregacja Nauki Wiary

KEY WORDS: grave delicts, delicta reservata, sexual abuse, minor, child pornography, Congregation for the Doctrine of the Faith 